\title{
ETHICS OF INFORMATION IN THE DIGITAL AGE'
}

\author{
Francisco Carlos Paletta* \\ Armando Manuel Barreiros da Silva**
}

ABSTRACT This study aims to present partial results on the research project Tecnologia da Informação em Biblioteca Digital e Sistemas Abertos - Estudos de Usuário da Informação na Web de Dados (Information Technology in Digital Library and Open Systems - Studies on Users of Information on Data Web), conducted by the School of Communications and Arts from University of São Paulo in cooperation with the Faculty of Letters of the University of Porto. The study presents reflections on ethical dimensions that accompany the current digital era. It discusses the importance of understanding the demands of the information user in the Data Web, with a view to teach a course named Ethics of Information at undergraduate programs in Librarianship, Archivology, Museology, and Information Science, which condenses these reflections and problems, Developing skills for an ethical action in the formation of the information professional in the network society.

Keywords: Ethics. Ethics of Information. Digital age. Information Science. Scientific Cooperation. Pedagogical Experience.

\footnotetext{
* Doutor em Ciências pela Universidade de São Paulo, Brasil. Pós-Doutorado pelo Instituto de Pesquisas Energéticas e Nucleares, Brasil. Professor e pesquisador da Universidade de São Paulo, Brasil. Líder do Grupo de Pesquisa Observatório do Mercado de Trabalho em Informação e Documentação, CNPq, Brasil. Presidente da Comissão de Cultura e Extensão Universitária da Escola de Comunicações e Artes da Universidade de São Paulo, Brasil. E-mail: fcpaletta@usp.br.

** Doutor em História Contemporânea de Portugal pela Universidade do Minho, Portugal. Professor Livre Docente do Departamento de Ciências da Comunicação e da Informação da Faculdade de Letras da Universidade do Porto, Portugal.

E-mail: malheiro@letras.up.pt.
}

\section{INTRODUCTION '}

Ther The focus of this study is to present a reflection on the application of Ethics in relation to the impact that has been caused in all plans by the post-World War II "information revolution". The interest that the "Ethics of Information", occupy in the research agenda of the main authors lacks specificity and even autonomy: are we faced with a "new" Ethics or an application of "Minimum Ethics"?

I Research Project with Support of FAPESP - Process 2016/073586. Information Technology in Digital Library and Open Systems Information User Studies in Data Web.

This study was presented at the XVII National Meeting on Research in Information Science. Phase I Result of the Research Project developed in collaboration with the line of interdisciplinary research of the nucleus of Information Science of the Department of Communication and Information Science from the Faculty of Letters of the University of Porto.
According to Stock and Stock (2015), the fixed point in Information Science is Information itself, the structured informational content that expresses knowledge. According to Buckland (1991), "information" presents three aspects of meaning, all objects of Information Science:

- information as process (a report / is informed)

- information as knowledge (information conveys knowledge)

- information as a "thing" (document)

This research project, in an international collaboration between the Faculty of Letters of the University of Porto - FLUP and the School of Communications and Arts of the University of São Paulo - ECA / USP, aims to present a set of reflections on interdisciplinary relations between Information and Ethics in the digital age. The 
project is led by the Observatório do Mercado de Trabalho em Informação e Documentação - CNPq - ECA_USP in scientific collaboration with the nucleus of Information Science of the Department of Communication and Information Sciences from the Faculty of Letters of the University of Porto.

As a practical and partial result of this study, we planned the creation of an "Ethics of Information" Course in the School of Communications and Arts of the University of São Paulo in an international cooperation with the Information Science Department of the Communication and Information Sciences Department from the Faculty of Letters of the University of Porto.

\section{WHAT IS ETHICS?}

A vast bibliography on the subject, of course, precludes the pretension of an exhaustive explanation and even of a quite complete synthesis. Therefore, the question posed in the title is intended to be a reduced but sufficient response, in such a way that the idea that there is a general ethics with applications in various domains and segments of human and social reality is well established.

Supporting inevitable response, there is the selective appeal to some authors and opportune works. And it is worth starting at the beginning, that is, Ethics is the "Branch of Philosophy that deals with questions about how we should live and therefore about the nature of right and wrong, good and evil, duty, obligation and other concepts" (O Livro da Filosofia: 2011: 341), Jim Hankinson, in turn, mixing humor and serious reflection pointed out that "One of the great pleasures of philosophers' lives is being able to tell everyone (not just children and dogs ) What they should do. This is called ethics" (HANKINSON, 1996, p.40). But the indispensable deepening of the concept guides us to the essential entry of the Encyclopedia Einaudi, extensive and dense and where it is possible to take a long explanation. But let us focus on the most striking given the purpose of this study:

Ethics as logic and metaphysics is a branch of Philosophy closely linked to religion and law, it deals with the norms that govern or should govern the relations of each individual with others and the values that each individual must perform in his behavior. Contrary to legal norms, those of ethics are not, however, imposed by a manifest or hidden repression, they are not sustained by a power, but at most by an authority, who cannot but call for a sense of responsibility in face of something that is beyond the individual: a god, society or humanity considered as a whole (KOLAKOWSKI, 1996, p.339, our translation).

It also guides us to the etymological roots of ethical and moral words. Ethos has origins in ancient Greece and signifies values, ethics, habits and harmony. It added, thus, all the habits and actions directed to the common good of a certain community. And this Greek word also assumed the meaning, for the ancient Greeks, of "man's abode," that is, nature: "Once processed through human activity in the form of culture, it makes the regularity proper to the Natural phenomena to be transposed into the size of the customs of a given society" (Ethos, in Wikipedia, url: https:// en.wikipedia.org/wiki/Ethos). The word Moral derives from the Latin mores, "relative to customs". It originated from the Romans' attempt to translate the Greek word, not translating it, however, in a complete way, since ethics had two complementary meanings for the Greeks: the former derived from ethos and meant, in a word, interiority of the human act, that is, that which generates a genuinely human action and which springs from within the moral subject (ethos points to the heart of action, to intention); the second one was related to the habits, customs, uses and rules, which is materialized in the social assimilation of values (Moral, In Wikipedia, url: https://en.wikipedia.org/wiki/Moral).

Thus, we have that Ethics and Morality are inseparable terms and concepts, but with a variable semantic relation: some people consider Moral to be wider than Ethics, appearing in the expression "Moral Sciences", affiliated with the "Sciences of the Spirit" and in opposition to the physical world; others, in line with the etymological record, understand that the reflexive and problematizing dimension fit the Ethics, while Moral is bound to the practical and normative conduct. The application of Ethics to socio-cultural and professional contexts is, in this second sense, of a strong moral tone. 
Regarding the application of ethics, through its emphasis on the moral dimension, it is important to the point out the meaning of

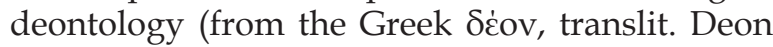
"duty, obligation" + $\lambda$ óyos, logos "science"). In contemporary moral philosophy it represents one of normative theories, according to which choices are morally necessary, forbidden or permitted, and in this sense joins the group of moral theories that guide our choices about what should be done. The term was introduced in 1834 by Jeremy Bentham to refer to the branch of ethics that deals with the foundations of duty and moral norms. It is known, also, under the name of "theory of the duty" (DEONTOLOGY) (Wikipedia, in: Wikipedia, URL: https://en.wikipedia.org/ wiki/Deontology). The deontological Code has become an expression used to explicitly mean rules adopted and practiced by a professional group (duties of a group).

Within Ethics, as a branch of Philosophy, there are several conceptions or currents:

Validity of moral judgments and mythological - religious tradition Judeo-Christian ethics and the authority of God;

Utilitarian or consequentialist solution: "The actions that increase happiness are fair, and the general end, upon which all our evaluations depend, is the greatest happiness of the greatest number" (KOLAKOWSKI, 1996, p.307);

Moral monism - "a code that implies the existence of a single autotelic value (value in itself), to which all others must be subordinated as means, and which claims that all specific moral problems can be solved in an unambiguous way by reference to this all-encompassing value (God, personal salvation, personal holiness, happiness, equality, freedom and more)" (KOLAKOWSKI, I996, p.310);

Difficulties of Kantianism - "There is only one morally good motivation, that is, the will to act according to duty as it expresses in a general principle. Therefore, an act is only morally praiseworthy if it is practiced by a sense of duty and not, for example, by inclination or piety. If it happens that my duty coincides with my spontaneous disposition, my act is morally empty: duty should only be fulfilled because it is duty, and not for other reasons. (...) This rigorist position seems unsustainable, above all by its insensibility to the moral life as a constitutive element of social realities" (KOLAKOWSKI, I996, p.3I4);

gradation requirement - "The thesis that human conduct, to be morally commendable, must be good in both acts and motivations, and both must be evaluated separately. ... The need to distinguish between what is perfect and what is reasonably good, between major evils and minor evils, seems obvious; and yet it is ignored by strictly rigorous moral teaching" (KOLAKOWSK, 1996, p.318-319);

Moral relativism. "Therefore, whoever claims to see no reason why one should accept something as a 'duty', why one should make use of the distinction between good and evil, and proclaim that there is absolutely no obligation to do something to in addition to what may be advantageous or satisfies his whim or fancy, such a person cannot be persuaded to a different position on the basis of arguments whose validity he does not accept" (KOLAKOWSKI, 1996, p.325).

With Jim Hankinson one can rehearse a collection of the accumulated "sensitivities", perceiving, after all, two great tendencies: the "deontological" have difficulty in defining what are the duties and the concomitant rights and from there the drift to the subjectivismobjectivism debate; and subjectivists inevitably approach cultural relativism: "A cultural relativist holds that no society has the right to say what is right or wrong in any other society" (HANKINSON, 1996: 42).

This being the general framework, what position should we follow?

It is now time to convene the Spanish ethicist Adela Cortina, who was convened, in fact, by this pertinent statement of Leszek Kolakovsky:

For this reason, the main moral problem of our times is this: how, despite all the ambiguities of moral life, it is possible to arrive at an understanding about a minimum code of fundamental human 
rights, a minimum list of prohibitions that cannot be invalidated by ideological considerations, by noble ends, by reason of State, by a decree, or, in what refers to it, by the majority vote (KOLAKOWSKI, 1996, p.325-326)

Cortina (VALENCIA, 1947), professor of Ethics at the University of Valencia and Director of the ÉTNOR Foundation, Ética de los Negocios y de las Organizaciones, is the author of several books: Ética mínima: introdução à filosofia prática [São Paulo: Martins Martins Fontes, 2009]. The "Minimum Ethics" has as an urgent task:

To build, from our traditions, our political and economic conditioning, our praxis and reflection, the lines of a morality for the secular city. And it would be sad if we rejected Nietzsche's morality of the camel (the morality of I should), fearful renounced the moral of the lion (the morality of I want), refused the children's play to be mysterious and aesthetic (the morality of I am), to end up embodying the morality of the chameleon (the morality of I adapt) (CORTINA, 2009, p. 17).

An Ethics for four current and major challenges: disputes ignited "between liberals and communals" who tend to lose intensity and slip to a certain hybridity; the strengthening of applied ethics and its involvement in social and philosophical life - sectors such as doctors and nurses, entrepreneurs, journalists and media workers, biologists, pharmacists, engineers and architects, have been working with ethical principles of their professions, in the search for fundamental values and in the elaboration of codes and ethical committees; multiculturalism with particular emphasis on liberal societies defending equal citizenship of all - how to respect the cultural identity of "minorities" and how to articulate any "particular ethics" with general Ethics; and globalization: "The possible communication between all places on Earth can serve to finally create networks dreamed of, from the Stoic world, of a cosmopolitan citizenship, or can be instrumentalized at the service of group interests, leaving the abandoned ones in the gutter, not so much from luck, but men with first and last name" (CORTINA, 2009, p. 25).

\section{ETHICS AND INFORMATION SCIENCE - ESSENTIAL DIALOGUE}

There are conditions for an Ethics of Information, with sufficient epistemological autonomy that allows it to investigate in the Era and current conjuncture the impacts and challenges of the informational revolution, triggered from the middle of the century. XX?

To further develop the question, it is important to know whether the Ethics of Information is essentially an application of the Ethics to the problems posed by the "Cyberspace" (LEVY), the "Space of Flows" (CASTELLS) or the "Infosphere" (Luciano Floridi ) or become a broader and more robust question of inquiry?

The second possibility has been from the late eighties of the last century, sustained by the philosopher and information scientist Capurro (MONTEVIDEO, 1945), who became an indispensable reference and presence prominent in the First International Symposium on Ethics of Information, João Pessoa, Paraíba, Brazil, 2010. It is therefore justified that due attention be paid to the proposal that it subscribes to and which can be characterized by some striking features, which are evident in the text Desafíos teóricos y prácticos de la Ética intercultural de la Información (In Simpósio de Ética da Informação (1 2010: João Pessoa). Ética da Informação: conceitos, abordagens, aplicações. Org. Gustavo Freire. João Pessoa: Ideia, 2010. cd-rom. P. 11-51).

The ICTs today have an extensive and strong impact in the most diverse sectors of our lives and so the Ethics of Information was born, but with an intercultural bias, that is, marked by respect for an ethical pluralism justified by the weight of specific cultural contexts. And, in this sense, the concern to dialogue with Authors who now reinforce, now circumvent this line Charles Ess, Luciano Floridi, Philip Brey and Ken Himma.

Capurro understands IIE (Intercultural Ethics of Information) as the relation between universalizable or universalized moral norms and local moral traditions. An example of universal morality is the Universal Declaration of Human Rights and in each particular culture there are specific ethical formulations. For him ethical reflection is a constant dialogue between universal and local morals, but it is possible to 
detect differences of position between Capurro and Cortina, since it does not emphasize the intercultural dimension of Ethics, recognizing it in its exact proportions, and seeks to recapture through a Kantianism capable of keeping alive in the Ethics the imperative of duty, certainly minimal, but sufficient. Capurro enumerates as practical challenges posed to the IIE the following: "privacy as an intercultural theme"; "The Global Ethics of Information at UNESCO"; "The IIE in South America and Caribbean": "Mysticism", "Santo Domingo and Latin American Networks of IE and IIE in Brazil.

Challenges that he approaches in an investigative way from the IIE, which thus appears as an anthropological and sociological course capable of probing and clarifying the different ethical-moral contexts. It is also curious to note that Capurro does not call for an investigative contribution to address these challenges to Information Science, being an epistemologist of this scientific course.

It is strange that the Information Science is not convened and the strangeness lies in our understanding of the Ethics of Information - application of the Minimum Ethics to the problems and challenges that the Digital Era is putting on increasingly and increasingly complex. This understanding leads us to distinguish plans: there is one for Ethics of Information and another for Information Science.

However, it is necessary to recognize the difficulty of an epistemological consensus around the so-called Information Science. To summarize explanations, we can say that there are two great perspectives in this recent field, marked by the strength of professional performance based on philological, literary and historical knowledge (diplomatic, paleographic and codicological) and technical-normative procedures, That the Cataloging Norms and all subsequent regulations are the complete exponent. On the one hand, and as a result of this eminently practical origin, a fragmentary and, at the most, a cumulative, and at most cumulative point of view, emerged in courses or sciences such as Library Science, Archivology/ Archives, Museology, Documentation and the Science of Information, each with professional justification and paradigmatic identity, to the point of remaining autonomous although able to cooperate with each other. And, on the other hand, the evolutionary that is coupled with the proposal of two paradigms for the area - the custodial, patrimonialist, historicist and technicist, and the post-custodial, informational and scientific (Armando Malheiro da Silva e Fernanda Ribeiro. Documentation/Information and their Paradigms: Characterization and importance in Research, Education and Professional Practice. Knowledge Organization: International Journal. ISSN 09437444. Vol. 39 (2012) 2, p.111-124) - which implies the evidence of an evolutionary process: several paradigms, of the courses mentioned, although they are autonomous by the corporative or professional imperative of their practitioners, share common methodological objects and procedures that lead to the inevitability of a fusion in a new course, more comprehensive and with greater scientific robustness than the previous ones - Information Science.

At the University of Porto is clearly followed the second exposed perspective with direct implications, namely in the topic in focus. When a transdisciplinary and interdisciplinary Information Science is defended and practiced, with a clear method (the Quadripolar Method) and a research agenda based on three areas (or parts of the study object) - information production or flow, organization and representation of the Information and informational behavior - that are projected in a transverse and fully applied activity such as information management, it is no longer necessary to transfer, for example, to the Ethics of Information an empirical research agenda as can be seen from the program outlined by Capurro, because it is fulfilled first in the scientific plane.

The Information Science has to work with clear operative concepts and the most elementary of all is, undoubtedly, information:

\begin{abstract}
Structured set of coded mental and emotional representations (signs and symbols) and modeled with/by social interaction, which can be registered in any material medium (paper, film, magnetic stripe, compact disc, etc.) and thus communicated in a way Asynchronous and multi-directed (SILVA, 2006, p.25).
\end{abstract}

Definition extensible to a human and social phenomenon from which six universal characteristics or properties are extracted:

Dynamic integration - the informational act is always implied or results both 
from the internal and external conditions and circumstances of the subject of the action;

Structuring by action (human and social) - the individual and / or collective act bases and structures the information structurally;

Pithiness - enunciation (maximum or minimum) of the active meaning, that is, of the founding and modeling action of information;

Quantification - linguistic, numerical or graphical coding is quantitatively measurable or measurable;

Reproducibility - information is reproducible without limits, enabling subsequent retention / storage;

Transmissibility - information (re) production is potentially transmissible or communicable (SILVA, 2006, p.25).

The information science is a social science that investigates the problems, themes and cases related to the perceptible and knowable information-communicational phenomenon through the confirmation or not of the properties inherent to the flow genesis, information organization and behavior: origin, collection, organization, storage, retrieval, interpretation, transmission, transformation and use of information (SILVA, 2006, p.140141). It has both a pure science component, which investigates the subject without taking into account its application, as a component of applied science, which develops products and services. It achieves results that constitute a vast and precious raw material for reflection, namely Ethics. And in this way the dialogue is essential: the questions of internal use, not shared in the organizational memory, deserve an extensive ethical consideration; as well as the binomial of secrecy-communication, that is, under what conditions and circumstances the secrecy is legitimate and under what conditions and circumstances the information-communicational process can become dangerous and threatening to the Common Good; And how the control of technological mediation can be made acceptable, and any restrictions on the use and access to digital devices and platforms are transformed as a threat to full freedom and individual responsibility... Three brief appendages of an extensive agenda that illustrates the dialogue Natural and strategic relationship between Ethics and Information Science - dialogue, which explicitly means close complementarity.

All science is a social activity determined by historical and socioeconomic conditions. In this way, the information society needs a science that studies the properties of information and the processes of its construction, communication and use. Today, the object of information science is no longer the object of librarianship and its venerable sisterly courses. It is no longer the library and the book, the documentation center and the document, the museum and the object, but it is the information that presents a focus (LE COADIC, 1996). Its scope is information in an infinite plurality of contexts and its mission summons the indispensable presence of Ethics of Information, helping to reflexively mark the results between the global vade mecum and the Universal Declaration of Human Rights (1948) and the professional "ethical or deontological codes", such as the Information Professional Code, which at various points do not harmonize, even seeming to oppose one another.

\section{FROM DIALOGUE TO PEDAGOGICAL PRACTICE: DESIGN OF A CURRICULAR EXPERIENCE}

The logical corollary of what has been exposed could not depart much from the point where we end. If it is essential in the philosophical space of the Ethics a reflection focused on the increasing and varied implications triggered by the Information Age with the vertigo of technological development that we are seeing throughout the World and if it is also obvious the close relationship between Ethics and Science Of information, we can only conclude from the need to reserve in the undergraduate programs, worldwide, the presence of a curricular unit in which the students are stimulated and trained to reflect ethically on the Current Time. There seems to be no room for disagreement on this position, but given the much that can and must still be done, there is inertia and lacking bold and consistent initiatives that must be urgently implemented. 
In the Network Society, strongly dependent on the Data Web, we find a new information user profile, where we urgently need to understand how its search model, access, appropriation and ethical use of information works.

In this context it is imperative to deal with a topic of relevant importance in the training of information professionals who will have to deal with this new dynamics in the role of mediators in a highly dependent Web Data Digital universe.

This is, in fact, the moment of sharing an initiative that involves two undergraduate programs in Universities of different countries, located in distant continents. On the one hand we have a degree in Information Science, created in the academic year 2001-2, as a joint initiative of the Faculties of Letters and Engineering of the University of Porto, initially shaped in eight semesters, the last devoted to a stage that ensured the employability of a significant number of students, then in 2007 reduced to six semesters by virtue of application of the Bologna Reform imposed on the European Higher Education Area and lastly reviewed, with no change in duration, but with a return to the introduction of the internship (limited to two months in a Course Designated Project) and presence, as optional, among others of the Ethics of Information. On the other side is the degree in Library Science and Documentation of the Department of Cultural Information of the School of Communications and Arts of the University of São Paulo. The Librarianship course was created in 1966 and its initial objective was to train professionals capable of planning, deploying and administering libraries and information centers. With the revolution imposed by the Digital Age, new logics and demands for professional skills were instituted.

As a pedagogical proposal of this research project in international collaboration with FLUP is the development of a study plan of the course "Ethics of Information" that can be implemented as an optional course and available to the entire USP community, or offered as a Culture and Extension activity.

We have here only a work base that is being adapted to something innovative and that helps, for example, to concretize in a real pedagogical way the internationalization of the educational mission of both the University of São Paulo and the University of Porto. The purpose of the curricular design presented here is to offer the same curricular unit in two different programs: baccalaureate and baccalaureate, conducted by professors of the respective Universities, but which begin to cooperate and to be able to have interventions Planned for this purpose. In this way, an educational scenario is created that allows for a growing number of didactic/ pedagogical procedures that are expected to be beneficial to both educational communities. The creation of a group in Moodle that can be frequented by the student population of the two classes, attending the same course, is one of the possible strategies to adopt within the experience that can be implemented and developed as a strategy of international cooperation.

The creation and joint offer, FLUP and ECA_USP, of the Ethics of Information, as an optional course and as a Culture and Extension activity, offered to the entire USP community, characterizes innovative activity and with positive impact in the internationalization initiatives of the University as well as in the Training of our students with multidisciplinary pedagogical practices.

In the Web page of the Degree in Information Science, in the optative courses of 2nd year, you can click and enter the file of the Ethics of Information course - (https://sigarra. up.pt/flup/pt/ucurr_geral.ficha_uc_view?pv_ ocorrencia_id $=375565)$, reproduced below: 


\section{ETHICS OF INFORMATION}

\section{SCIENTIFIC AREA: APPLIED SOCIAL SCIENCES}

RESPONSIBLE UNIT: DeparTaMento de CiênCIAS da COMUNICAÇ̃̃o FLUP

\section{Departamento de Informação e Cultura ECA/SP}

Course: Bachelor's Degree with a Teaching Certificate in Information Sciences - FLUP

Bachelor's Degree in Library Science and Documentation - ECA/USP

Professor: Prof. Dr. Armando Manuel Barreiros da Silva - FLUP

Prof. Dr. Francisco Carlos Paletta - ECA/USP

WORKLOAD:

THEORETICAL-PRACTICE: 4 HOURS / LECTURE/ 6 ECTS

CLASS FREQUENCY: 56

SELF-STUDY: 66

RESEARCH WORK/RESEARCH: 40

TOTAL: 162

AIMS:

To help students understand the ethical basis of the infocommunicational process so they:

- can distinguish between Ethics of Information and deontology of information professionals (there are relations between these two levels, they represent specific and distinct dimensions).

- acquire, as an operational competence, the awareness that the production, selection, storage of information and its diffusion through communication take place implying interesting and deep relations with Ethics.

- be able to have a reasoned opinion on the Ethics of Information, to distinguish Ethics from Professional Ethics and to explain to what extent ethics relates to the various procedures and activities of the information-communicational process

\section{RESULTS OF LEARNING AND COMPETENCES:}

It is intended that students discover the importance of Ethics of Information in the informationcommunicational process, distinguish Ethics of Deontology and get perspectivity of the theme focusing the present and future of the Information Age. Topics 1 and 2 of the program contribute to the first goal; Topic 3 for the second goal and topics 4 and 5 for the last goal. 


\section{ETHICS OF INFORMATION}

\section{SCIENTIFIC AREA: APPLIED SOCIAL SCIENCES}

PROGRAM:

1. Ethics as branch of Philosophy and distinction in the face of Morals and Deontology

2. The Information Age Challenges Ethics

3. Ethics of Information: origin and principles

4. Ethics of Information and Deontology of the Information Professional: distinction and points of contact

5. Information and Communication: from the statute of law to the limitations of duty

\section{TEACHING METHODS AND LEARNING ACTIVITIES:}

The classes will be based on the expository method, with the formulation of questions to be debated with the students and using some texts that they should read and discuss. The evaluation will consist of a written paper and a final exam based on the analysis of the question formulated from selected texts.

\section{BIBLIOGRAPHY:}

Araújo, Luís de; Sob o signo da ética. ISBN: 972-8594-09-7

Bonhoeffer, Dietrich; Éthique

Comissão de Ética para os Profissionais da Informação no Brasil ; Código de ética para os profissionais da informação e comunicação.

Habermas, Jurgen; A Ética do discurso, Edições 70, 2014. ISBN: 978-972-44-1582-6

Kant, Immanuel, 1724-1804; Fundamentação da metafísica dos costumes. ISBN: 972-0-41077-9

Kolakowski, Leszek; Ética (In Enciclopédia Eunaudi, vol. 37 - Conceito Filosofia/Filosofias. Lisboa:

Imprensa Nacional-Casa da Moeda, 1997. ISBN 972-27-0869-4. P. 300-339.)

Moore, Adam D. , ed; Ethics of Information: privacy, property and power, University of Washington

Press, 2005

Renaud, Michel 340; Ética, crise e sociedade. ISBN: 978-989-8139-90-0

Rosas, João Carlos; Merrill, Roberto, Org.; Ética, tecnologia e democracia, Edições Humus, 2010.

ISBN: 978-989-8139-70-2

Savater, Fernando; Ética para um jovem. ISBN: 972-23-1657-5

Silva, Armando Malheiro da; A Pesquisa e suas aplicações em Ciência da Informação: implicações éticas (In Ética da Informação: conceitos, abordagens, aplicações. E-book do I Simpósio Brasileiro de Ética da Informação, João Pessoa, 18 a 19 de março de 2010. Gustavo Henrique de Araújo Freire (org.) Org. Gustavo Henrique de Araújo Freire. João Pessoa: I)

Tasset, José L.; La Ética y las pasiones, Universidad de La Coruña Servicio de Publicaciones, 1999. ISBN: 84-95322-05-6

\section{EVALUATION COMPONENTS:}

Test

Written Work

Total:

100.00

The Final Score (FS) is calculated as follow: FS $=$ Written Work $\times 0,3+$ Final Exam $\times 0,7$ 


\section{FINAL CONSIDERATIONS}

All science is a social activity determined by historical and socioeconomic conditions. In this way the information society needs a science that studies the properties of information and the processes of its construction, communication and use. Today, the object of information science is no longer the object of librarianship and its venerable sisterly courses. It is no longer the library and the book, the documentation center and the document, the museum and the object, but it is the information that presents a focus (LE COADIC, 1996).

In this scenario of real transformations, the social responsibility of information professionals grows, both as producers of knowledge in the scientific field and as facilitators in the communication of information to users who need it in society, regardless of the social spaces where they live and the roles they play In the productive system (FREIRE, 2010).

The construction of a smarter Internet is moving in the direction of producing a revolution in the digital universe of the organization of information and knowledge. With the use of new technologies, it is imperative to use Information and Communication Technologies to make the process of finding information and generating new knowledge more agile. It is at this point that a new user of information emerges with new demands for computational resources and new skills in producing new knowledge (CASTELLS, 2005).

According to Ribeiro (2010), in the framework of the new emerging paradigm, which we call post-custodial, scientific and informational, and in the face of these new mediation logics and this new type of mediators, what is the role of professionals in Information Science in Society? Does it remain confined to the domain of a few technical and normative specificities applied to the organization and representation of information, in order to provide access? Where does your previous role as guardian of the information memory, as a factor of identity of a people? Where does its mediating function reside and to what extent is it circumscribed?

The new paradigm of Information Science, in consolidation, presupposes that the study of information is not confined to empirical practice, composed of a uniform and uncritical set of modes / rules of procedure, of only apparently "aseptic" or neutral processes of creation, Classification, ordering and retrieval, but it assumes the imperative to inquire, to understand and to make explicit (to know) the social information, through theoretical and scientific models that are increasingly demanding and effective..

The consolidation of Information Science as a scientific area with solid and consistent theoretical and methodological foundations is, in our view, a guarantee that students in this field of knowledge will be prepared to face the new challenges of networked society and will be able to study and understand the information-communicational phenomenon in all its complexity. And it is in this scenario that the Ethics of Information, central focus of this work is highlighted.

In 2010, the First Symposium on Information Ethics was held in 2010, and in 2016, under the 13th CONTECSI and II TOI International Congress on Information Technology and Organization, held by the Faculty of Economics and Administration in collaboration with the School of Communications and Arts - USP, the II International Symposium on Information Ethics, two initiatives that open space for a multiplication of effects in order to deepen and disseminate solid Information Ethics in Brazil and beyond.

Consolidating this initiative in 2017 will be the third edition of SBEI - Simpósio Brasileiro de Ética da Informação, under the III TOI - International Congress on Information Technology and Organization, organized by Professor Isa Maria Freire, UFPB and Professor Francisco Paletta, USP, with the international collaboration of Professor Armando Malheiro, FLUP.

The sharing of the same course of undergraduate level in different universities, but cooperating with each other, constitutes a relevant step towards the objectification of this desideratum and can be followed closely by researchers and academics of other institutions aware of the need to offer to students of the University. Field of Information Science, Information / Documentation, critical thinking skills about the enormous and multiple ethical challenges of the Information Age in which we are immersed. 


\section{A ÉTICA DA INFORMAÇÃO NA ERA DIGITAL}

RESUMO Este trabalho tem por objetivo apresentar reflexões sobre resultados de projeto de pesquisa "Tecnologia da Informação em Biblioteca Digital e Sistemas Abertos - Estudos de Usuário da Informação na Web de Dados", conduzido na Escola de Comunicações e Artes da Universidade de São Paulo em colaboração com a Faculdade de Letras da Universidade do Porto. O trabalho apresenta reflexões sobre dimensões éticas que acompanham a atual era digital. Discute a importância em entender as demandas do usuário da informação na Web de Dados, com vista a ministrar nos cursos de graduação de Biblioteconomia, Arquivologia, Museologia, e Ciência da Informação, uma disciplina: Ética da Informação, que condense essas reflexões e problemática, desenvolvendo competências para uma ação ética na formação do profissional da informação na sociedade em rede.

Palavras-chave: Ética. Ética da Informação. Era Digital. Ciência da Informação. Cooperação Científica. Experiência Pedagógica.

\section{REFERENCES}

ARAÚJO, E. A. ; BEZERRA, M. A. A. A ética no contexto epistemológico da ciência da informação. In: BORGES, M. M. ; CASADO, E. S. A ciência da informação criadora de conhecimento. Coimbra : Imprensa da Universidade de Coimbra, 2009. p. 225-234.

BENTHAM, J. Déontologie on science de la morale: owvrage posthume. Paris : Charpentier, 1834.

BORKO, H. Information Science: What is it? American Documentation, v.19, n.1, p.3-5, 1968. Available from: http://www. josesales.com.br/arquivos / BORKO $\% 20$ Harold \% 20- \% 20Ci \% C3\% A Ancia \% 20da \% 20 informa $\%$ C3\% A7\% C3\% A3o.pdf . Access on: June 12, 2016.

BUCKLAND, M. K. Information and information systems. New York: Pergamon, 1991

BUCKINGHAM, Will. O Livro da Filosofia. Rio de Janeiro: Globo Livros, 2013. 352 p.

BRUYNE, P. ; HERMAN, J. ; SCHOUTHEETE, M. Dynamique de la recherche en sciences sociales: les pôles de la pratique méthodologique. França : Presses Universitaires de France, 1974.
CAPURRO, R. Desafíos teóricos y prácticos de la Ética intercultural de la Información. In: Simpósio de ética da informação: conceitos, abordagens, aplicações, 1, João Pessoa. Anais... João Pessoa: Ideia, 2010. 1 CD-ROM.

CAPURRO, R. ; BIELBY, J. International Center for Ethics of Information (ICIE) and International Review of Ethics of Information (IRIE). Alemanha : ICIE/IRIE, 1999. Availble from: http://www.i-r-i-e.net. Access on: June 16, 2016.

CARTA Internacional dos Direitos Humanos. Declaração Universal dos Direitos do Homem. Adoptada e proclamada pela Assembleia Geral na sua Resolução 217A (III) de 10 de Dezembro de 1948. Available from: <http://www.gddc. $\mathrm{pt} /$ direitos-humanos/textos-internacionais-dh/ tidhuniversais/cidh-dudh.html>. Access on: June 16, 2016.

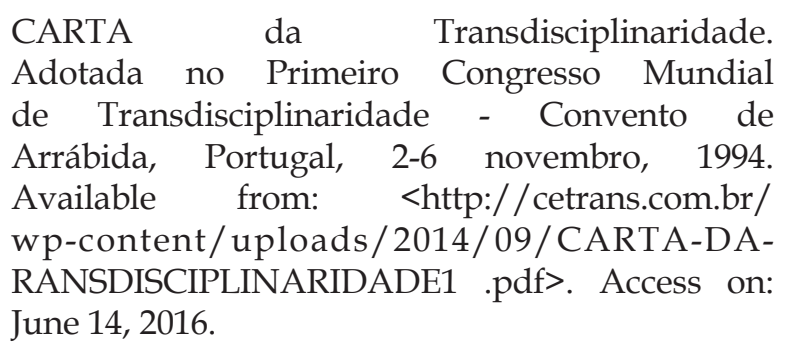


CASTELLS, M. ; CARDOSO, G. The network society: from knowledge to policy. Washington, DC: Johns Hopkins Center for Transatlantic Relations, 2005.

CASTRO, A. (Coord.). O curso de licenciatura em ciência da informação na Universidade do Porto: dez anos de actividade pedagógica e cientifica. Porto: FLUP/FEUP, 2011.

CIRNE, M. T. ; FERREIRA, S. M. A ética para os profissionais da informação audiovisual: o devir tecnológico a moldar uma atitude. Cadernos BAD, n.1, p.84-91,2002. Available from: http:// www.bad.pt/publicacoes/index.php/cadernos/ article/view/881/880. Access on: June 12, 2016.

CODIGO de Ética para os Profissionais da Informação em Portugal. Lisboa: BAD, INCITE e APDIS, 2000. Available from: http://www. iscteiul.pt/Libraries/PDFs_SID/codigoetica.sflb. ashx. Access on: June 13, 2016.

CORTINA, A. Ética mínima: introdução à filosofia prática. São Paulo: Martins Fontes, 2009.

DEONTOLOGIA. In: Wikipedia. Available from: https:/ / pt.wikipedia.org/wiki/Deontologia Access on: June 13, 2016.

DINIZ, D. ; TERRA, A. Plágio: palavras escondidas. Rio de Janeiro: FIOCRUZ, 2014.

ETHOS. In: Wikipédia. Available from: https:// pt.wikipedia.org/wiki/Ethos. Access on: June 13, 2016.

FREIRE, I. Reflexões sobre uma ética da informação na sociedade em rede. Ponto De Acesso,v.4, n.3, p.113-133, 2010. Available from: http://www.portalseer.ufba.br/index.php/ revistaici/article/view/4518/3567. Access on: June 12, 2016.

HANKINSON, J. O Especialista Instantâneo em Filosofia. Lisboa: Gradiva, 1996.

KOLAKOWSKI, L. Ética: conceito, filosofia/ filosofias. In: Enciclopedia Einaudi, v. 37, p.300339, 1997.

Le COADIC, Yves-François. A ciência da informação. Brasília, DF: Briquet de Lemos, 1996.
MORAL. In: Wikipedia. Available from:< https:/ / pt.wikipedia.org/wiki/Moral>. Access on: June 13, 2016.

RIBEIRO, F. Da mediação passiva à mediação pós-custodial: o papel da ciência da informação na sociedade em rede. Informação e Sociedade, João Pessoa, v. 1, n. 20, p.63-70, 2010. Available from: <https://repositorioaberto. u p.pt / bitstream / $10216 / 39370 / 2$ / fribeirodamediacao000112989.pdf>. Access on: June 12, 2016.

SILVA, A. M. da . A informação: da compreensão do fenómeno e construção do objeto cientifico. Porto: Edições Afrontamento/CETAC, 2006.

SILVA, A. M. da ; RIBEIRO , F. Das «ciências» Documentais a ciência da informação: ensaio epistemológico para um novo modelo curricular. 1 ed. Porto : Edições Afrontamento, 2002.

STOCK, W. G. ; STOCK M. Handbook of Information Science. Alemanha: De Gruyter, 2015.

\section{ACKNOWLEDGEMENTS}

We would like to thank FAPESP - Apoio Pesquisa - Process no. 2016/07358-6: Tecnologia da Informação em Biblioteca Digital e Sistemas Abertos Estudos de Usuário da Informação na Web de Dados. 